\title{
Host Range of Phytophthora capsici from Pumpkin and Pathogenicity of Isolates
}

\author{
D. Tian and M. Babadoost, Department of Crop Sciences, University of Illinois, Urbana 61801
}

\begin{abstract}
Tian, D., and Babadoost, M. 2004. Host range of Phytophthora capsici from pumpkin and pathogenicity of isolates. Plant Dis. 88:485-489.

This study was conducted to determine the host range of Phytophthora capsici isolates from pumpkin and virulence of the isolates on pumpkin cultivars. The pathogenicity of $P$. capsici isolates from pumpkin was evaluated on 45 species of herbaceous plants, including 36 species of crops grown in rotation sequences with pumpkin and nine species of weeds that commonly grow in pumpkin fields in Illinois. Plants were grown in the greenhouse, and 4-week-old seedlings were inoculated by adding $5 \mathrm{ml}$ of a zoospore suspension $\left(2 \times 10^{5}\right.$ spores per $\mathrm{ml}$ of water) onto the soil surface around the stem of each plant in the pot. Twenty-two crop species and two weed species became infected with P. capsici and developed symptoms. P. capsici was reisolated from all of the symptomatic plants by culturing tissues onto a semiselective medium (PARP). Also, $P$. capsici was detected in $87.5 \%$ of symptomatic plants by a polymerase chain reaction (PCR) method using PCAP and IT5 primers. Cucurbits and pepper were the most susceptible hosts of P. capsici. Five crop species or varieties, beet (Beta vulgaris), Swiss-chard (Beta vulgaris var cicla), lima beans (Phaseolus lunatus), turnip (Brassica rapa), and spinach (Spinacia oleracea), and one weed species, velvet-leaf (Abutilon theophrasti), were found to be hosts of $P$. capsici for the first time. Six isolates of $P$. capsici were inoculated onto six pumpkin cultivars (three processing and three jack-o-lantern pumpkins) in the greenhouse and resulted in significant interactions between pathogen isolates and pumpkin types. $P$. capsici isolates were more virulent on jack-o-lantern pumpkins than on processing pumpkins.
\end{abstract}

Additional keywords: Cucurbita moschata, C. pepo, Phytophthora blight

Phytophthora blight, caused by Phytophthora capsici Leonian, has become one of the most serious threats to production of cucurbits, eggplant, and pepper in the United States and worldwide $(2,4,6,11,14,18,21)$. Recently, the incidence of damping-off, foliar blight, and fruit rot on pumpkins caused by $P$. capsici has dramatically increased in Illinois $(1,2)$, causing yield losses of up to $100 \%$.

Jack-o-lantern pumpkin (Cucurbita pepo) is an important crop in Illinois, and approximately $90 \%$ of the commercial processing pumpkin (Cucurbita moschata) produced in the United States are grown in Illinois (2). The economic importance of Phytophthora blight to cucurbit crops, particularly to processing pumpkin, lack of resistant or tolerant cultivars (1), and inadequate effect of chemicals on controlling the diseases prompted our investigation to utilize all effective practices to develop feasible strategies to manage the disease and minimize crop losses. Crop rotation to decrease initial inoculum of $P$. capsici in infested fields has been included as an important component of disease manage-

Corresponding author: M. Babadoost

E-mail: babadoos@uiuc.edu

Accepted for publication 18 December 2003.

Publication no. D-2004-0220-01R

(c) 2004 The American Phytopathological Society ment strategies. Most pumpkin growers in Illinois follow at least a short-term crop rotation. However, most growers have experienced heavy losses when carrot, lima beans, pea, snap bean, and tomato were grown prior to pumpkin (M. Babadoost, unpublished). To establish effective crop rotation sequences for management of Phytophthora blight of cucurbits, determination of host range of $P$. capsici in the field is essential $(4,11,17,21)$.

Forty-nine plant species have been reported infected by $P$. capsici (4). Among the major hosts of $P$. capsici are red and green peppers (Capsicum annuum), watermelon (Citrullus lanatus), cantaloupe (Cucumis melo), honeydew melon ( $C$. melo), cucumber (Cucumis sativus), blue Hubbard squash (Cucurbita maxima), acorn squash (Cucurbita moschata), gourd (C. moschata), processing pumpkin ( $C$. moschata), yellow squash (Cucurbita pepo), zucchini squash (C. pepo), tomato (Lycopersicon esculentum), black pepper (Piper nigrum), and eggplant (Solanum melongena).

$P$. capsici can strike host plants at any stage of growth $(4,8)$. The pathogen infects root, crown, stem, leaf, and fruit. Pre- and post-emergence damping-off on cucurbit crops and other host plants are common symptoms of $P$. capsici infection. Seedling death occurs in wet and warm $\left(20\right.$ to $\left.30^{\circ} \mathrm{C}\right)$ soil conditions $(4,8)$. It has been reported that plants are more susceptible to $P$. capsici in seedling stages than as mature plants $(9,20)$. Thus, screening seedlings for susceptibility to $P$. capsici is a more reliable approach for determining host range of $P$. capsici and plant resistance.

Determination of variation among isolates of $P$. capsici is essential for developing effective measures for controlling this pathogen in the fields. Distinct pathogenic strains of $P$. capsici from eggplant, pepper, pumpkin, squash, tomato, and watermelon have been reported $(7,11,16,17,21)$. Tamietti and Valentino (21) grouped $P$. capsici isolates into 13 classes depending upon their ability to infect different plant species. They reported that all isolates tested were pathogenic on bell pepper, $95 \%$ on squash, $79 \%$ on tomato, $58 \%$ on nightshade, $38 \%$ on eggplant, $33 \%$ on pea, $20 \%$ on melon, and $8 \%$ on French bean. Ristaino (17) studied $P$. capsici isolates from cucurbits and pepper and reported significant interspecific interactions. Also, significant differences in virulence of $P$. capsici isolates from pumpkin and pepper have been reported $(7,11)$.

Visual inspection of symptoms and isolation of the pathogen from infected tissue have been the methods employed for diagnosing the disease caused by $P$. capsici $(2,4,15)$. However, this method is a timeconsuming approach, and it is not a reliable method if opportunistic organisms grow on infected tissue. Therefore, a rapid and more reliable diagnostic method for detection of $P$. capsici in plant tissue is needed. The polymerase chain reaction (PCR) assay is one approach that allows rapid detection of Phytophthora species in plants $(12,13,19,22,23)$.

The objectives of this research were: (i) to determine the susceptibility of crops grown in rotation with cucurbit crops, and of weeds that commonly grow in cucurbit fields, to $P$. capsici; (ii) to assess the virulence of $P$. capsici isolates from pumpkin on pumpkin cultivars; and (iii) to implement a molecular method for rapid detection of $P$. capsici isolates from pumpkin in plant tissue.

\section{MATERIALS AND METHODS}

Fungal isolates and preparation of inoculum. $P$. capsici was isolated from infected pumpkin tissues collected from Illinois by culturing diseased tissue onto a semiselective medium (PARP) $(8,15)$. The isolates were maintained on lima bean agar (LBA; Difco Laboratories, Detroit, MI). Six isolates of $P$. capsici, three A1 and three A2 mating types from processing pumpkins, were used in this study (Table 1). Sporangial suspensions were prepared 
from 5-day-old culture plates of $P$. capsici grown on LBA at $24^{\circ} \mathrm{C}$ under continuous white fluorescent light. Ten milliliters of sterilized distilled water (SDW) was added to each plate, and the sporangia were dis- lodged using a soft brush. Sporangial suspensions from six isolates (equal numbers of plates of each isolate) were mixed. The suspension was then incubated at $20^{\circ} \mathrm{C}$ for $1 \mathrm{~h}$ to allow the sporangia to release their

Table 1. Source and mating types of Phytophthora capsici isolates from processing pumpkin fields in Illinois used in inoculations

\begin{tabular}{lccccc}
\hline Isolate & $\begin{array}{c}\text { Plant } \\
\text { part }\end{array}$ & $\begin{array}{c}\text { Field } \\
\text { location }\end{array}$ & $\begin{array}{c}\text { Year } \\
\text { isolated }\end{array}$ & $\begin{array}{c}\text { Mating } \\
\text { type }\end{array}$ & $\begin{array}{c}\text { Growth } \\
\text { pattern }^{\mathbf{z}}\end{array}$ \\
\hline Pc-15 & Petiole & Manito & 2000 & $\mathrm{~A} 2$ & Stellate \\
Pc-20 & Seedling & S. Pekin & 2000 & A1 & Stellate \\
Pc-24B & Fruit & Manito & 2000 & A1 & Stellate \\
Pc-35\#4 & Petiole & Machinaw & 2001 & A2 & Rosaceous \\
Pc-34\#7 & Petiole & Allentown & 2001 & A2 & Stellate \\
Pc-38\#15 & Vine & Manito & 2001 & A1 & Petaloid \\
\hline
\end{tabular}

y All locations are in central Illinois.

${ }^{\mathrm{z}}$ Growth pattern on potato dextrose agar.

zoospores. Zoospores were separated from the empty sporangia by passing the suspension through a four-layered facial tissue. The concentration of zoospores was adjusted to $2 \times 10^{5}$ zoospores per $\mathrm{ml}$ of water using a hemacytometer (\#3120, Hausser Scientific Co., Horsham, PA) and used in inoculation.

Host range. Forty-five species of plants were screened for their susceptibility to $P$. capsici (Table 2). Sixteen soybean cultivars (Bell, Harosoy 13, Harosoy 16, Harosoy 63, L75-3735, L76-1988, L83-570, L85-2352, L85-3059, L89-1581, L933258, Resink, Saloan, Williams, Williams 82, Union) were included in this test. Seeds of the plants were sown in $10-\mathrm{cm}-$ diameter plastic pots (one seed per pot) containing steamed soil mix (soil:sand:

Table 2. Susceptibility of 45 plant species to Phytophthora capsici isolates ${ }^{\mathrm{v}}$ from pumpkin

\begin{tabular}{|c|c|c|c|c|c|c|c|}
\hline \multirow[b]{2}{*}{ Family } & \multirow[b]{2}{*}{ Common name } & \multirow[b]{2}{*}{ Scientific name } & \multirow[b]{2}{*}{ Cultivar } & \multicolumn{2}{|c|}{ Diseased plants $(\%)$} & \multirow[b]{2}{*}{ Reisolation } & \multirow[b]{2}{*}{ PCR detection } \\
\hline & & & & 3 days & 12 days & & \\
\hline \multirow[t]{2}{*}{ Amaranthaceae } & Pigweed $^{\mathrm{w}}$ & Amaranthus etroflexus & & 0 & 0 & $-{ }^{\mathrm{x}}$ & Negative \\
\hline & Water hemp ${ }^{\mathrm{w}}$ & Amaranthus rudis & & 0 & 0 & - & Negative \\
\hline \multirow{4}{*}{ Chenopodiaceae } & Beet $^{\mathrm{y}}$ & Beta vulgaris & Ruby Queen & 21.7 & 55.6 & + & Negative \\
\hline & Lamb's-quarters ${ }^{w}$ & Chenopodium album & & 0 & 0 & - & Negative \\
\hline & Spinach $^{\mathrm{y}}$ & Spinacia oleracea & Old Dominion & 41.7 & 83.9 & + & Positive \\
\hline & Swiss-chardy & Beta vulgaris var. cicla & Rhubarb & 24.9 & 64.8 & + & Negative \\
\hline Compositae & Cockleburw & Xanthium strumarium & & 0 & 0 & - & Negative \\
\hline \multirow[t]{8}{*}{ Cruciferae } & Radish & Raphanus sativus & French Breakfast & 21.6 & 60.8 & + & Positive \\
\hline & Turnip ${ }^{y}$ & Brassica rapa & Purple Top & 27.7 & 53.9 & + & Positive \\
\hline & Broccoli & Brassica oleracea & Nomad & 0 & 0 & - & Negative \\
\hline & Cabbage & Brassica oleracea & Jersey Wakefield & 0 & 0 & - & Negative \\
\hline & Cauliflower & Brassica oleracea & Snow Ball X & 0 & 0 & - & Negative \\
\hline & Kale & Brassica oleracea & White Russian & 0 & 0 & - & Negative \\
\hline & Kohlrabi & Brassica oleracea & Early White Vienna & 0 & 0 & - & Negative \\
\hline & Mustard & Brassica nigra & Tatsoi & 0 & 0 & - & Negative \\
\hline \multirow[t]{8}{*}{ Cucurbitaceae } & Cantaloupe & Cucumis melo & Sweet Granite & 80.5 & 100 & + & Positive \\
\hline & Cucumber & Cucumis sativus & Cayenne & 75.9 & 100 & + & Positive \\
\hline & Gourd & Cucurbita pepo & Bird House & 66.9 & 95.9 & + & Positive \\
\hline & Honeydew melon & Cucurbita melo & Honey Roch & 80.7 & 100 & + & Positive \\
\hline & Melon & Pisum melo & Annanas & 88.6 & 100 & + & Positive \\
\hline & Squash & Cucurbita pepo & Sebring F1 & 88.6 & 100 & + & Positive \\
\hline & Watermelon & Citrullus lanatus & SWT6703 & 80.7 & 100 & + & Positive \\
\hline & Zucchini & Cucurbita pepo & Dark Green & 90.9 & 100 & + & Positive \\
\hline \multirow[t]{2}{*}{ Gramineae } & Corn & Zea mays & Wisconsin Black & 0 & 0 & - & Negative \\
\hline & Wheat & Triticum aestivum & Clark & 0 & 0 & - & Negative \\
\hline Labiatae & Basil & Ocimum basilicum & Thai & 0 & 0 & - & Negative \\
\hline \multirow[t]{4}{*}{ Leguminosae } & Green bean & Phaseolus vulgaris & Bush Blue Lake & 30.8 & 52.6 & + & Positive \\
\hline & Lima bean ${ }^{y}$ & Phaseolus lunatus & Ford Hook 242 & 31.6 & 63.8 & + & Positive \\
\hline & Snow pea & Pisum sativus & Snow Flake & 10.6 & 51.9 & + & Negative \\
\hline & Soybean $^{z}$ & Glycine $\max$ & & 0 & 0 & - & Negative \\
\hline \multirow[t]{2}{*}{ Liliaceae } & Chives & Allium schoenoprasum & Herb & 0 & 0 & - & Negative \\
\hline & Onion & Allium cepa & Red Wether Field & 20.6 & 41.9 & + & Positive \\
\hline Malvaceae & Velvet-leaf ${ }^{\mathrm{w}, \mathrm{y}}$ & Abutilon theophrasti & & 34.9 & 78.3 & + & Positive \\
\hline \multirow[t]{2}{*}{ Poaceae } & Crabgrass $^{\mathrm{w}}$ & Digitaria sanguinalis & & 0 & 0 & - & Negative \\
\hline & Sandburw & Cenchrus incertus & & 0 & 0 & - & Negative \\
\hline \multirow[t]{5}{*}{ Solanaceae } & Eggplant & Solanum melongena & Classic & 35.6 & 75.8 & + & Positive \\
\hline & Nightshade $^{w}$ & Solanum nigrum & & 45.7 & 92.9 & + & Positive \\
\hline & Pepper & Capsicum annuum & California wonder & 51.4 & 100 & + & Positive \\
\hline & Tobacco & Nicotiana tabacum & Sacred & 24.9 & 70.7 & + & Positive \\
\hline & Tomato & Lycopersicon esculentum & Popreco & 45.8 & 85.7 & + & Positive \\
\hline \multirow[t]{4}{*}{ Umbelliferae } & Carrot & Daucus carota & Red Core Chantanay & 30.6 & 85.9 & + & Positive \\
\hline & Celery & Apium graveolens & Giant Red & 0 & 0 & - & Negative \\
\hline & Dill & Anethum graveolens & Long Island & 0 & 0 & - & Negative \\
\hline & Parsley & Petroselinum crispum & Moss Curled & 0 & 0 & - & Negative \\
\hline Zygophyllaceae & Puncture vine ${ }^{w}$ & Tribulus terrestris & & 0 & 0 & - & Negative \\
\hline
\end{tabular}


vermiculite, 1:1:1) and were grown on a greenhouse bench at 18 to $26^{\circ} \mathrm{C}$. Fourweek-old seedlings were inoculated by adding the suspension of motile zoospores over the soil surface around the plant in each pot $(5 \mathrm{ml}$ per seedling per pot). Control seedlings received $5 \mathrm{ml}$ of SDW. Seedlings were watered before inoculation to keep the soil wet. After inoculation, the pots were placed in plastic trays containing water that kept the soil moist for at least 12 $h$. The seedlings were then placed on the greenhouse bench and watered twice daily. Beginning the second day after inoculation, seedlings were evaluated for development of lesions on stems, defoliation, and damping-off symptoms every day for 3 weeks. The experiment was performed using a randomized complete block design with four replications each with 10 plants. The experiments were conducted twice. Beginning the second day after inoculation, plants were evaluated for disease development until 21 days after inoculation. Percentage of plants with symptoms 3 and 12 days after inoculation are presented (Table 2).

Virulence test. Three jack-o-lantern pumpkin cultivars (Gold Rush, Gold Medal, Pik-A-Pie) and three processing pumpkin cultivars (Dickinson, H-401, H698) were used to determine virulence of $P$. capsici isolates to pumpkins. Seeds were planted in $10-\mathrm{cm}$-diameter pots containing steamed soil mix (soil:sand:vermiculite, $1: 1: 1)$ and grown in the greenhouse. Fourweek-old seedlings were inoculated by adding $5 \mathrm{ml}$ of the zoospore suspension to each pot as described above. Control plants received SDW. Beginning the second day after inoculation, plants were evaluated for disease incidence until 21 days after inoculation. Disease incidence was assessed as percentage of seedlings that died. Area under disease progress curve (AUDPC) was calculated using the formula: $\mathrm{AUDPC}=n \Sigma i=1\left(X_{i+1}+X_{i}\right)\left(t_{i+1}\right.$ $\left.-t_{i}\right) / 2$, where $X_{i}=$ disease incidence at the $i$ th observation, $t_{i}=$ days at the $i$ th observation, and $n=$ total number of observations. The experiment was performed using a randomized complete block design with four replications, each with 10 plants. The experiment was conducted twice. Data were analyzed using analysis of variance procedures of SAS.

Reisolation and molecular detection of pathogen. Symptomatic and asymptomatic tissues of roots and stems of the seedlings were assayed for the presence of $P$. capsici by culturing tissue on PARP medium $(8,15)$. Also, tissues of the symptomatic and asymptomatic roots and stems were assayed for the presence of $P$. capsici using the modified PCR procedures developed by Ristaino et al. (19). DNA was extracted from symptomatic and asymptomatic plants using the Bio-101 kit (Bio101, Inc., Carlsbad, CA). Aliquots of $1 \mu \mathrm{l}$ of the extract were used as the DNA tem- plate for PCR in $25-\mu$ l reaction mixture containing $0.1 \mu \mathrm{l}$ of PCAP $\left(5^{\prime}-\right.$ TCCTCCGCTTATTGATATGC) and $0.1 \mu \mathrm{l}$ of IT5 (5'-GGAAGTAAAAGTCGTAACA AGG) primers. The thermal cycling was processed at $95^{\circ} \mathrm{C}$ for $2 \mathrm{~min}$, followed by 35 cycles consisting of $94^{\circ} \mathrm{C}$ for $1 \mathrm{~min}$, $60^{\circ} \mathrm{C}$ for $1 \mathrm{~min}$, extension at $72^{\circ} \mathrm{C}$ for 1 min, and a final extension at $72^{\circ} \mathrm{C}$ for 10 min using PTC-200 (Peltier) Thermal Cycler (MJ Research, Inc., Waltham, MA). Amplified fragments were electrophoresed on a $2 \%$ agarose gel at $50 \mathrm{UV}$ for $1.5 \mathrm{~h}$.

\section{RESULTS}

Host range. Plants of 22 crop species and two weed species exhibited dampingoff symptoms (Table 2). Plants of 14 crop species and seven weed species did not develop any symptoms. All plants from Cucurbitaceae and Solanaceae, and most of the plants from Chenopodiaceae, families became infected and developed symptoms. Cucurbits and pepper were the most susceptible to $P$. capsici, as more than 50 and $95 \%$ of their seedlings became infected and developed symptoms within 3 and 12 days after inoculation, respectively. Infection in beet, carrot, eggplant, green bean, lima bean, nightshade, radish, snow pea, spinach, Swiss-chard, tobacco, tomato, turnip, and velvet-leaf developed symptoms slowly. However, more than $50 \%$ of the seedlings of these crops developed symptoms within 12 days of inoculation (Table 2). Onion was less susceptible, and only $41.9 \%$ of its seedlings exhibited symptoms. No obvious changes in symptom development were observed after 12 days postinoculation. $P$. capsici was reisolated from all of the symptomatic plants on PARP culture medium. Using the PCR method, $P$. capsici was detected in all symptomatic plants with the exception of beet, snow pea, and Swiss-chard. We were unable to detect $P$. capsici in these species by the PCR method for reasons unknown. None of the control plants developed disease symptoms, and attempts to isolate $P$. capsici from their tissues were unsuccessful. Thus, the results of control plants were not presented. Control tissue was processed as diseased tissue was.

Basil, broccoli, cabbage, cauliflower, celery, chive, corn, dill, kale, kohlrabi, mustard, parsley, soybean, and wheat seedlings did not develop any symptoms. Likewise, the weed species of cocklebur, crab grass, lamb's-quarters, pigweed, puncture vine, sandbur, and water hemp did not develop symptoms. Attempts to reisolate $P$. capsici from asymptomatic plant tissues of inoculated plants, or detect the pathogen by the PCR method, did not provide any indication of presence of $P$. capsici in these plants.

Virulence test. The relative virulence of six isolates of $P$. capsici on six pumpkin cultivars was evaluated by comparing percentage of plant death. Percentage of plant death was significantly affected by pathogen isolate and pumpkin type $\times$ isolate interactions (Table 3 ). There was no significant effect of pumpkin cultivar on percentage of plant death. There was significant difference in percentage of seedling death between jack-o-lantern and processing pumpkins (Table 4, Fig. 1). The standard deviations in percentage of plant death for jack-o-lantern and processing pumpkin cultivars were 38.27 and 34.28 , respectively.

\section{DISCUSSION}

The results of this study agree with the reports by other investigators $(4,7,11,14$, $17,24)$ that cucurbits and pepper are the most susceptible hosts of $P$. capsici. Lists of $P$. capsici hosts have been published by other investigators (3-5), with that of Erwin and Ribeiro (4) as the most comprehensive list worldwide. They state that 49 species of herbaceous and woody plants can be infected by $P$. capsici. Our investigations focused on plants used in rotation sequences with pumpkin in Illinois. Most of the plant species that have been previously reported as hosts of $P$. capsici (3-5)

Table 3. Analysis of variance for areas under disease progress curves (AUDPCs) ${ }^{\mathrm{x}}$ on pumpkins inoculated with six isolates of Phytophthora capsici

\begin{tabular}{lccr}
\hline Source & $\mathbf{d f}^{\mathbf{y}}$ & Mean square & $\boldsymbol{P} \boldsymbol{F}$ \\
\hline Experiment & 1 & $21,371.6$ & 0.071 \\
Reps (experiment) & 3 & $6,828.6$ & 0.531 \\
Type $\times$ experiment & 1 & $9,908.4$ & 0.270 \\
Cultivar $\times$ experiment & 5 & $18,536.0$ & 0.062 \\
Type $\times$ cultivar $\times$ experiment & 5 & $16,810.5$ & 0.125 \\
Isolate $\times$ experiment & 5 & $10,435.9$ & 0.271 \\
Type & 1 & $206,668.7$ & $<0.001$ \\
Type $\times$ isolate $\times$ experiment & 5 & $3,313.7$ & 0.746 \\
Cultivar (type) & 2 & $9,090.3$ & 0.235 \\
Isolate & 5 & $39,537.8$ & $<0.001$ \\
Type $\times$ isolate & 5 & $36,113.9$ & $<0.001$ \\
Isolate $\times$ cultivar (type) & 10 & $25,372.0$ & $<0.001$ \\
Isolate $\times$ cultivar $\times$ experiment & 25 & $5,615.1$ & 0.585 \\
\hline
\end{tabular}

x AUDPC $=n \sum i=1\left(X_{i+1}+X_{i}\right)\left(t_{i+1}-t_{i}\right) / 2$, where $X_{i}=$ disease incidence at the $i$ th observation, $t_{i}=$ days at the $i$ th observation, and $n=$ total number of observations.

y Degree of freedom.

z Jack-o-lantern and processing pumpkins. 
Table 4. Areas under disease progress curves (AUDPC) on six pumpkin cultivars in an evaluation of virulence of six Phytophthora capsici isolates from pumpkin

\begin{tabular}{|c|c|c|c|c|c|c|}
\hline \multirow[b]{3}{*}{ Isolate } & \multicolumn{6}{|c|}{ AUDPC $^{y}$ on different cultivars } \\
\hline & \multicolumn{3}{|c|}{ Jack-o-lantern pumpkins } & \multicolumn{3}{|c|}{ Processing pumpkins } \\
\hline & Gold Rush & Gold Medal & Pik-A-Pie & Dickinson & Hybrid-401 & Hybrid-698 \\
\hline Pc-15 & $216.8 \mathrm{a}^{\mathrm{z}}$ & $216.8 \mathrm{a}$ & $208.3 \mathrm{bc}$ & $186.7 \mathrm{a}$ & $168.3 \mathrm{~b}$ & $188.4 \mathrm{a}$ \\
\hline Pc-20 & $213.2 \mathrm{ab}$ & $206.7 \mathrm{abc}$ & $216.6 \mathrm{ab}$ & $156.8 \mathrm{~b}$ & $175.8 \mathrm{ab}$ & $172.5 \mathrm{~b}$ \\
\hline Pc-24B & $226.7 \mathrm{a}$ & $208.3 \mathrm{ab}$ & $226.7 \mathrm{a}$ & $191.7 \mathrm{a}$ & $180.0 \mathrm{a}$ & $201.8 \mathrm{a}$ \\
\hline Pc-34\#7 & $218.4 \mathrm{a}$ & $201.6 \mathrm{bcd}$ & $200.0 \mathrm{bc}$ & $158.4 \mathrm{~b}$ & $172.5 \mathrm{ab}$ & $166.7 \mathrm{bc}$ \\
\hline Pc-35\#4 & $191.7 \mathrm{c}$ & $190.0 \mathrm{~d}$ & $196.7 \mathrm{c}$ & $143.3 \mathrm{c}$ & $155.0 \mathrm{c}$ & $155.8 \mathrm{c}$ \\
\hline Pc-38\#15 & $200.0 \mathrm{bc}$ & $195.0 \mathrm{~cd}$ & $201.8 \mathrm{bc}$ & $152.5 \mathrm{~b}$ & $152.5 \mathrm{c}$ & $163.3 \mathrm{bc}$ \\
\hline $\operatorname{LSD}(P=0.05)$ & 15.8 & 12.9 & 17.4 & 9.1 & 11.4 & 13.4 \\
\hline
\end{tabular}

y $\mathrm{AUDPC}=n \sum i=1\left(X_{i+1}+X_{i}\right)\left(t_{i+1}-t_{i}\right) / 2$, where $X_{i}=$ disease incidence at the $i$ th observation, $t_{i}=$ days at the $i$ th observation, and $n=$ total number of observations.

${ }^{\mathrm{z}}$ In each column, the values with a letter in common are not significantly different from each other according to Fisher's protected LSD $(P=0.05)$.
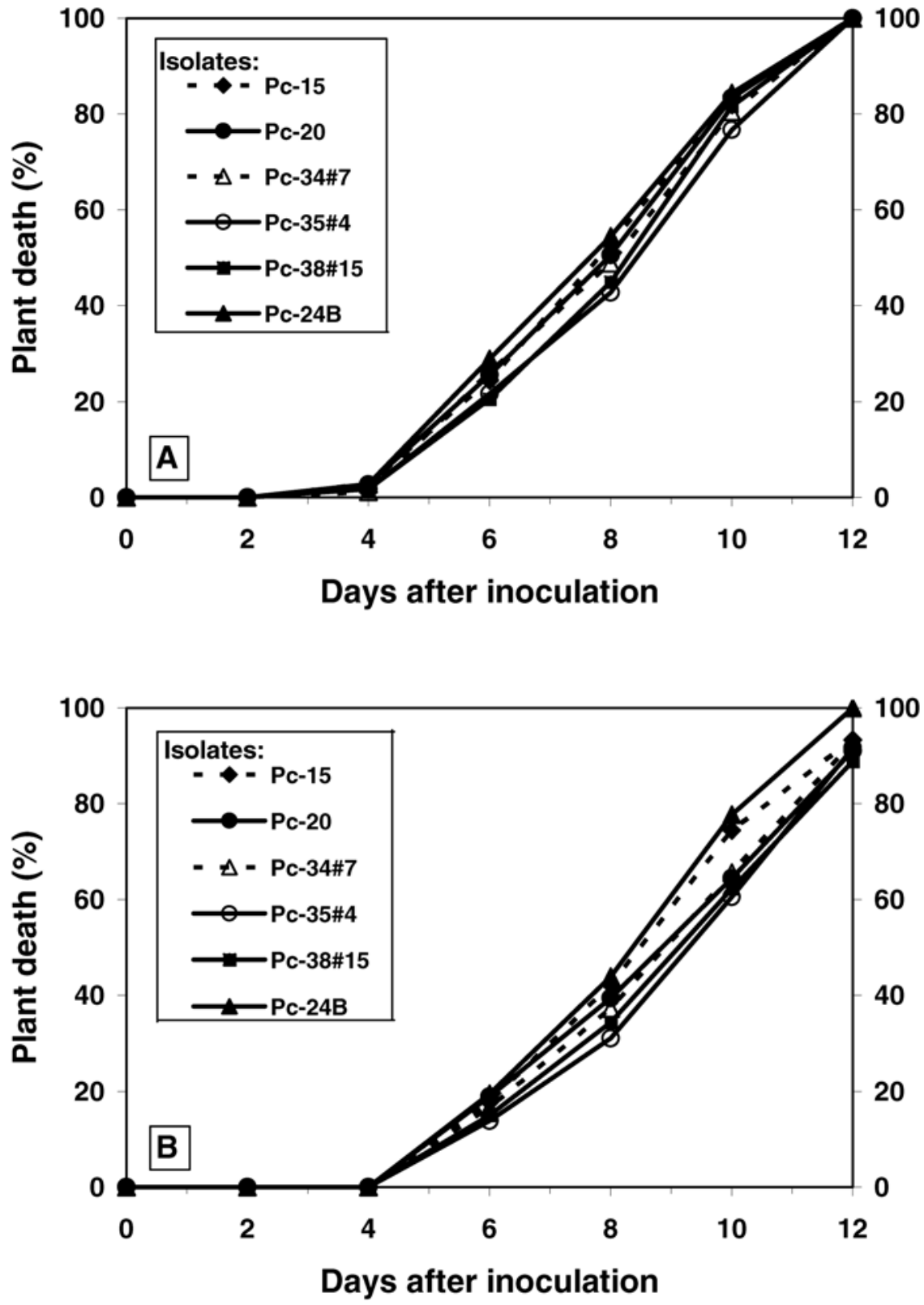

Fig. 1. Incidence of plant death in $\mathbf{A}$, jack-o-lantern and $\mathbf{B}$, processing pumpkins following inoculation of plants with six isolates of Phytophthora capsici. For each isolate, data represent mean disease incidence in 240 plants of three cultivars. can be infected by isolates from Illinois pumpkin. However, cauliflower (Brassica oleracea var. botrytis), which has been listed as a host (4), was not infected in our test. This indicates that either cauliflower is not a host of $P$. capsici, it is resistant at early growth stages and may become susceptible as the plant matures, or $P$. capsici isolates from Illinois pumpkin do not cause disease on cauliflower while the isolates from other areas possibly do.

This is the first report of beet (Beta vulgaris), Swiss-chard (Beta vulgaris var. cicla), lima bean (Phaseolus lunatus), turnip (Brassica rapa), spinach (Spinacia oleracea), and velvet-leaf (Abutilon theophrasti) as hosts of $P$. capsici. Nightshade and velvet-leaf are weeds that commonly grow in commercial fields of pumpkins and other cucurbits. Soybean, corn, and wheat, the major crops grown in Illinois, were not infected with $P$. capsici in our study, and there is no report indicating that these crops could be infected with $P$. capsici. This report is expected to help in establishing effective rotations and weed management programs for sustainable pumpkin production.

Since inoculation tests were conducted under conditions highly conducive for disease development (tender greenhousegrown seedlings and high inoculum dose), it is possible that some of the species susceptible to $P$. capsici in the greenhouse may not be as susceptible under field conditions. Field studies could provide additional information on the susceptibility of the species tested in the greenhouse in this study.

We found that isolates of $P$. capsici differ in virulence, which agrees with the reports by Hwang et al. (7), Lee et al. (11), and Ristaino (17). The isolates used in this study were less virulent on processing pumpkins than on jack-o-lantern pumpkins. Therefore, more effective measures are needed to manage $P$. capsici in jack-olantern pumpkin fields. None of the pumpkin cultivars used in this study was resistant to $P$. capsici. This may be another indication that there is no measurable resistance in pumpkin cultivars to $P$. capsici, as reported by Erwin and Ribeiro (4) and Latin and Rane (10). Consequently, the effectiveness of other methods (e.g., cultural practices, chemical treatments, induced resistance) should be investigated to develop effective integrated approaches for management of $P$. capsici in pumpkin fields.

The PCR method for detection of $P$. capsici in plant tissues developed by Ristaino et al. (19) and modified in this study detected P. capsici in infected plants of 21 of $24(87.5 \%)$ species. Thus, this PCR method is a rapid and reliable tool for detection of $P$. capsici in plants, particularly at early infection stages. Since management of Phytophthora blight is based on prevention of disease spread, a rapid detection of $P$. capsici at early stages of disease 
development in the field is very useful, as fungicide applications (e.g., dimethomorph spray) could suppress the growth and sporulation of the pathogen (M. Babadoost, unpublished data).

\section{ACKNOWLEDGMENTS}

This research was supported in part by funds from North Central Region SARE (Project No. AG 256205-0034-014), Illinois Department of Agriculture (Project No. SA 02-101), and Nestle Food, Inc.

\section{LITERATURE CITED}

1. Babadoost, M. 2000. Outbreak of Phytophthora foliar blight and fruit rot in processing pumpkin fields in Illinois. Plant Dis. $84: 1345$.

2. Babadoost, M., and Islam, S. Z. 2003. Fungicide seed treatment effects on seedling damping-off of pumpkin caused by Phytophthora capsici. Plant Dis. 87:63-68.

3. C.M.I. 1985. C.M.I. description of pathogenic fungi and bacteria, No. 836. Phytophthora capsici. CAB, Kew, England.

4. Erwin, D. C., and Ribeiro, O. K. 1996. Phytophthora Diseases Worldwide. American Phytopathological Society, St. Paul, MN.

5. Farr, D. F., Bills, G. F., Chamuris, G. P., and Rossman, A. Y. 1995. Fungi on Plants and Plant Products in the United States. American Phytopathological Society, St. Paul, MN.

6. Hwang, B. K., and Kim, C. H. 1995. Phytophthora blight of pepper and its control in Korea. Plant Dis. 79:221-227.

7. Hwang, B. K., Kim, Y. J., and Kim, C. H. 1996. Differential interactions of Phytophthora capsici isolates with pepper genotypes at various growth stages. Eur. J. Plant Pathol. 102:311-316.

8. Islam, S. Z., and Babadoost, M. 2002. Effect of red-light treatment of seedlings of pepper, pumpkin, and tomato on the occurrence of Phytophthora damping-off. HortScience 37:678-681.

9. Kim, Y. J., Hwang, B. K., and Park, K. W. 1989. Expression of age-related resistance in pepper plants infected with Phytophthora capsici. Plant Dis. 73:745-747.

10. Latin, R. X., and Rane, K. 1999. Identification and Management of Pumpkin Diseases. BP17, Purdue University, Lafayette, IN.

11. Lee, B. K., Kim, B. S., Chang, S. W., and Hwang, B. K. 2001. Aggressiveness to pumpkin cultivars of isolates of Phytophthora capsici from pumpkin and pepper. Plant Dis. 85:497-500.

12. Lee, H. K., Tewari, J. P., and Turkington, T. K. 2001. A PCR-based assay to detect Rhynchosporium secalis in barley seed. Plant Dis. 85:220-225.

13. Lee, S. B., White, T. J., and Taylor, J. W. 1993. Detection of Phytophthora species by oligonucleotide hybridization to amplified ribosomal DNA spacers. Phytopathology 83:177-181.

14. Leonian, L. H. 1922. Stem and fruit blight of pepper caused by Phytophthora capsici. Phytopathology 12:401-408.

15. Papavizas, G. S., Bowers, J. H., and Johnston, S. A. 1981. Selective isolation of Phytophthora capsici from soils. Phytopathology 71:129133.

16. Polach, F. J., and Webster, R. K. 1972. Identification of strains and inheritance of pathogenic- ity in P. capsici. Phytopathology 62:20-26.

17. Ristaino, J. B. 1990. Interspecific variation among isolates of Phytophthora capsici from pepper and cucurbit fields in North Carolina. Phytopathology 71:129-133.

18. Ristaino, J. B., and Johnston, S. A. 1999 Ecologically based approaches to management of Phytophthora blight on bell pepper. Plant Dis. 83:1080-1089.

19. Ristaino, J. B., Trout, C. L., and Gregory, P. 1998. PCR amplification of ribosomal DNA for species identification in the plant pathogen genus Phytophthora. Appl. Environ. Microbiol. 64:948-954.

20. Roberts, P. D., Urs, R. R., and McGovern, R. J 2000. Age and varietal response of tomato to infection by Phytophthora capsici. (Abstr.) Phytopathology 90:S65.

21. Tamietti, G., and Valentino, D. 2001. Physiological characterization of a population of Phy tophthora capsici Leon. from northern Italy. J. Plant Pathol. 83:1101

22. Tooley, P. W., Bunyard, B. A., Carras, M. M. and Hatziloukas, E. 1997. Development of PCR primers from internal transcribed spacer region II for detection of Phytophthora species infecting potatoes. Appl. Environ. Microbiol. 63:1467-1475.

23. Trout, C. L., Ristaino, J. B., Madritch, M., and Wangsomboondee, T. 1997. Rapid detection of Phytophthora infestans in late blight-infected potato and tomato using PCR. Plant Dis. 81:1042-1048.

24. Zitter, T. A., Hopkins, D. L., and Thomas, C. E. 1996. Compendium of Cucurbit Diseases. American Phytopathological Society, St. Paul $\mathrm{MN}$ 